\title{
Expression of Certain Pulmonary Proteins in the Tracheal Mucosa and Lungs of Pashmina, Bakerwali and Non-Descript Goats of U.T.s of Ladakh and Jammu \& Kashmir
}

\author{
Neelofar Nabi ${ }^{1}$ \\ https://orcid.org/0000-0002-3871-0329 \\ Kamal Sarma ${ }^{1^{*}}$ \\ https://orcid.org/0000-0002-6333-5516 \\ Jonali Devi ${ }^{1}$ \\ https://orcid.org/0000-0001-6630-2659
}

Ram Saran Sethi ${ }^{2}$

https://orcid.org/0000-0003-0416-8946

Devendra Pathak ${ }^{3}$

https://orcid.org/0000-0002-3999-3906

Jasvinder Singh Sasan ${ }^{1}$

https://orcid.org/0000-0002-7175-477X

${ }^{1}$ S.K. University of Agricultural Sciences \& Technology of Jammu, Faculty of Veterinary Sciences \& Animal Husbandry, R.S. Pura, Jammu, J\&K, India; ${ }^{2}$ Guru Angad Dev Veterinary and Animal Sciences University, School of Animal Biotechnology, Ludhiana, Punjab, India; ${ }^{3}$ Guru Angad Dev Veterinary and Animal Sciences University, College of Veterinary Science, Ludhiana, Punjab, India.

Editor-in-Chief: Alexandre Rasi Aoki

Associate Editor: Renata Marino Romano

Received: 2020.12.10; Accepted: 2021.06.10.

*Correspondence: kamalsarma73@yahoo.com; Tel.: +91-9419112492 (K.S.).

\section{HIGHLIGHTS}

- The expression of various proteins such as Vimentin, SMA, PCNA and VEGE did not show a definitive trend among the goat breeds.

- $\quad$ So, these may not be so useful as markers while studying effect of altitudes on the respiratory tissue in animal models.

Abstract: The aim of this present study was to localize alveolar macrophages, Proliferating cell nuclear antigen (PCNA), Smooth muscle actin (SMA), Vimentin and Vasculo-endothelial growth factor (VEGF) in the tracheal epithelium and lung alveoli in three important breeds of goats namely, Pashmina, Bakerwali and non-descript goats by standard immunohistochemical methods. Large pulmonary macrophages were observed in the lung sections of all the three breeds of goat. Macrophages were observed in the alveolar septa and airway epithelium. The mean macrophage count for Pashmina, Bakerwali and non-descript goat were recorded as $23.4 \pm 1.47,27.8 \pm 0.68$ and $21.4 \pm 0.70$, respectively. The PCNA activity was intense in the alveolar epithelial cells of lungs in Pashmina and Bakerwali goats and very high in the lung tissue of nondescript goat. The PCNA activity was intense in the bronchial epithelial cells of lungs in Bakerwali goat. Strong reaction of SMA was observed in the submucosa of bronchioles of Pashmina and Bakerwali goats. The submucosa of the tracheal tissue showed a strong reaction of SMA in the non-descript goat and moderate in the submucosa of trachea in the Bakerwali goat. A number of vimentin-positive cells were found in the lung parenchyma in both Pashmina and Bakerwali goats. Also, there was a strong reaction of vimentin mainly in submucosal area in non-descript goat. The VEGF activity was found to be intense in the 
lung alveoli of Bakerwali goat and strong in Pashmina and non-descript goats. The tracheal epithelium was moderately reactive to VGEF in all the three goats.

Keywords: Immunohistochemistry; lung; pashmina; bakerwali; non-descript goats.

\section{INTRODUCTION}

The diversity of different climatic conditions and altitudes within J\&K state has given rise to differential adaptive mechanisms that enable goats to cope effectively with a variety of stressful environmental conditions. Jammu city (with an altitude of $327 \mathrm{~m}$ to $412 \mathrm{~m}$ ), shares the same climatic conditions like the rest of North-Western India. The U.T. of Ladakh is the dry temperate region with much of its altitude ranging from $3,000 \mathrm{~m}(9,800 \mathrm{ft})$ to $5,000-5,500 \mathrm{~m}(16,000-18,050 \mathrm{ft})$. Both the regions have a considerable difference in altitude too. The knowledge about the biochemical mechanisms which enable high-altitude animals like Pashmina goats to survive and function properly under hypoxic stress environments can provide important information about the nature of physiological adaptation. Studies on a number of high altitude and temperate zone vertebrates indicates that modifications of hemoglobin function due to hypoxic conditions typically play a key role in mediating an adaptive response to chronic hypoxia [1]. Again, the Bakerwali is a very important breed of goat of Jammu division of the J\&K, which is known for its migratory habits. The non-descript goats of this region is a habitant of the plain region of low altitude.

Anatomical study on the respiratory system has been conducted in domestic mammals by various workers in horse [2], goat [3,4], Black Bengal goat [5] and sheep [6]. Goat shows distinctive organization of respiratory organs as compared to large ruminants [7]. However, review of literature reveals that the studies on the histological aspects of respiratory organs of goat are very scant as compared to those of other domestic animals. Also the detailed study on the effect of geo-climatic conditions like altitude on the respiratory organs and concomitant blood profiles is very scant in the available literature.

The expression of certain proteins in the respiratory tract might be influenced by the altitude. Hence, the present study has been designed to study the possible variations of expression of certain proteins in trachea and lungs of Pashmina, Bakerwali and non-descript goats of Union Territory of J\&K as these three breeds are the normal habitants of different altitudes. Moreover, this is the first study of its kind in this aspect in available literature.

\section{MATERIALS AND METHODS}

Trachea and lung samples were collected from adult Pashmina goats from slaughter houses of Ladakh of J\&K state. Similar organs of Bakerwali goats and non-descript goats were collected from slaughter houses in and around Jammu city. Minimum 10 samples from each goat breed were collected. representative tissue samples from trachea and lungs of all the goats were preserved in $10 \%$ Neutral Buffered Formalin (NBF) solution [8] and these tissues were processed for paraffin block preparation by alcohol-benzene schedule [8]. With help of rotary microtome, tissue sections of $5 \mu \mathrm{m}$ thickness were obtained on clean glass slides with the help of rotary microtome.

The sections in duplicate were mounted on super frost positively charged slides (Fisher Scientific). After dewaxing and rehydration of these slides, the heat induced antigen retrieval was done in citrate buffer (AR 3 solution, Biogenex) and heating in microwave at $95^{\circ} \mathrm{C}$ for 10 minutes and $98^{\circ} \mathrm{C}$ for 5 minutes. Slides were then left for $30 \mathrm{~min}$ in hot buffer and washed in $0.1 \mathrm{M}$ phosphate buffered saline (at $\mathrm{pH} 7.4)$. The endogenous peroxidase activity was blocked by immersing the sections in $3 \%(\mathrm{v} / \mathrm{v}) \mathrm{H}_{2} \mathrm{O}_{2}$ in methanol for 20 min followed by washing in $0.1 \mathrm{M}$ phosphate buffered saline (at $\mathrm{pH} 7.4)$. Sections were blocked with normal horse serum (Vector's Laboratories USA) in order to prevent non-specific antibodies binding. The sections were incubated with primary antibodies at $4^{\circ} \mathrm{C}$ for overnight in staining box. Then, washing was done in $0.1 \mathrm{M}$ phosphate buffered saline (at $\mathrm{pH}$ 7.4). After washing, the sections were incubated with universal secondary antibody (Vector Laboratories, USA). 3, 3'-diaminobenzidine tetra hydrochloride (DAB) (Vector Laboratories, USA) was used as chromogen with Gill's III haematoxylin counterstaining. The sections were washed in running tap water, then dehydrated and cleared and finally mounted with DPX. 
Table 1. Antibodies used for Immunohistochemical study.

SI. No. Antibody Source

Time and temperature of incubation

\begin{tabular}{llll}
\hline 1. & Anti- Vimentin & Biogenex laboratory & Overnight at $4^{\circ} \mathrm{C}$ \\
2. & Anti- Smooth muscle & $\begin{array}{l}\text { SantCruz } \\
(1: 200)\end{array}$ & Biotechnology \\
3. & actin & Biogenex laboratory & Overnight at $4^{\circ} \mathrm{C}$ \\
4. & Anti-VENA & Biogenex laboratory & Overnight at $4^{\circ} \mathrm{C}$ \\
\hline
\end{tabular}

The paraffin sections were subjected to immunohistochemical staining to localise the immunopositive macrophages in lung tissue.

\section{Procedure for immunostaining}

Xylene

Ethanol, $100 \%$ 90\%, 70\%

Air dry

$3 \% \mathrm{H}_{2} \mathrm{O}_{2}$

Distilled water

Boiling TRIS EDTA buffer

Distilled water

1x PBS

Dark chamber with $1 \%$ BSA

Primary antibody

1x PBS

Secondary antibody

$1 \times$ PBS

Chromogen (Vector-VIP SK4600, DAB SK-4100)

Distilled water

Counterstain with methyl green $(\mathrm{H}-3402)$

Running tap water

$70 \%$ Alcohol

95\% Alcohol

$100 \%$ Alcohol

Xylene

Mounting of slides under microscope
:2 changes for 10 min each

$: 1$ change 2 min each

$: 2 \mathrm{~min}$

:20 min

$: 5 \min$

$: 10 \mathrm{~min}$

$: 10 \mathrm{~min}$

:3washings, 5 min each

$: 1$ hour

:2 hours

:3washings, 5 min each

:30 minutes

:3washings, 5 min each

:10 min

$: 1 \mathrm{~min}$

$: 1 \mathrm{~min}$

$: 5$ min

$: 1$ dip

:1 dip

$: 1 \mathrm{dip}$

$: 2$ changes, 5 min each

\section{Reagents used}

The primary and secondary antibodies used to localize macrophages are described hereunder:

Table 2. Antibodies used for Immunohistochemical demonstration of pulmonary macrophages.

\begin{tabular}{cccccc}
\hline $\begin{array}{c}\text { Primary } \\
\text { antibody }\end{array}$ & \multicolumn{1}{c}{ Supplier } & Species & Dilution & \multicolumn{1}{c}{ Secondary antibody } & Dilution \\
\hline $\begin{array}{l}\text { Macrophage } \\
\text { MCA874G }\end{array}$ & $\begin{array}{l}\text { AbDSerotec; Raleigh, } \\
\text { North Carolina }\end{array}$ & Mouse & $1: 50$ & $\begin{array}{l}\text { Polyclonal rabbit anti-mouse } \\
\text { immunoglobulins/ HRP (Dako }\end{array}$ & $1: 100$ \\
& & & P0447) & \\
\hline
\end{tabular}

\section{Reagents used in this study were:}

$3 \% \mathrm{H}_{2} \mathrm{O}_{2}$ : 1 part

Distilled water : 9 parts

\section{Preparation of 10x Tris Borate EDTA stock solution}

To prepare 1 liter of 10X TRIS borate EDTA following components were dissolved in $600 \mathrm{~mL}$ distilled water: 
Tris base $(\mathrm{MW}=121): 108 \mathrm{~g}$

Boric acid (MW $=61.8): 55 \mathrm{~g}$

0.5 M EDTA $(\mathrm{pH} 8.0) \quad: 40 \mathrm{~mL}$

Final volume was adjusted to 1 liter with distilled water. To prepare a $1 \mathrm{X}$ working solution from 10X stock buffer, $10 x$ stock buffer was mixed with deionized water at 1:9 ratio.

\section{1\% BSA:}

$\mathrm{BSA}=0.25 \mathrm{~g}$

$1 \times \mathrm{PBS}=25 \mathrm{~mL}$

\section{RESULTS}

\section{Lung macrophages}

In the present study, lung sections from goats showed normal alveolar septa, airways and large blood vessels. Large pulmonary macrophages were observed in the lung sections of all the three breeds of goat (Fig. 1). Macrophages were observed in the alveolar septa and airway epithelium. The mean macrophage count for Pashmina, Bakerwali and non-descript goat were recorded as $23.4 \pm 1.47,27.8 \pm 0.68$ and $21.4 \pm 0.70$, respectively.

\section{Proliferating cell nuclear antigen (PCNA)}

The PCNA activity was intense in the alveolar epithelial cells of lungs in Pashmina and Bakerwali goats. Also, the activity was very high in the lung tissue of non-descript goat. The PCNA activity was intense in the bronchial epithelial cells of lungs in Bakerwali goat (Figures 2, 3).

\section{Smooth muscle actin (SMA)}

Strong reaction of SMA was observed in the submucosa of bronchioles of Pashmina and Bakerwali goats. The submucosa of the tracheal tissue showed a strong reaction of SMA in the non-descript goat. There was a moderate reaction of SMA in the submucosa of trachea in this Bakerwali goat (Figures 4, 5, $6)$.

\section{Vimentin}

A number of vimentin-positive cells were found in the lung parenchyma in Pashmina and Bakerwali goats. Also, there was a strong reaction of vimentin mainly in submucosal area in the non-descript goat. The tracheal submucosa showed an intense reaction of vimentin in the submucosa in all the goats (Figures $7,8,9,10)$.

\section{Vasculo-endothelial growth factor (VEGF)}

The VEGF activity was found to be intense in the lungs of Bakerwali goat. Also, the reaction was strong in alveoli in Pashmina and non-descript goats (Figures 11, 12). 


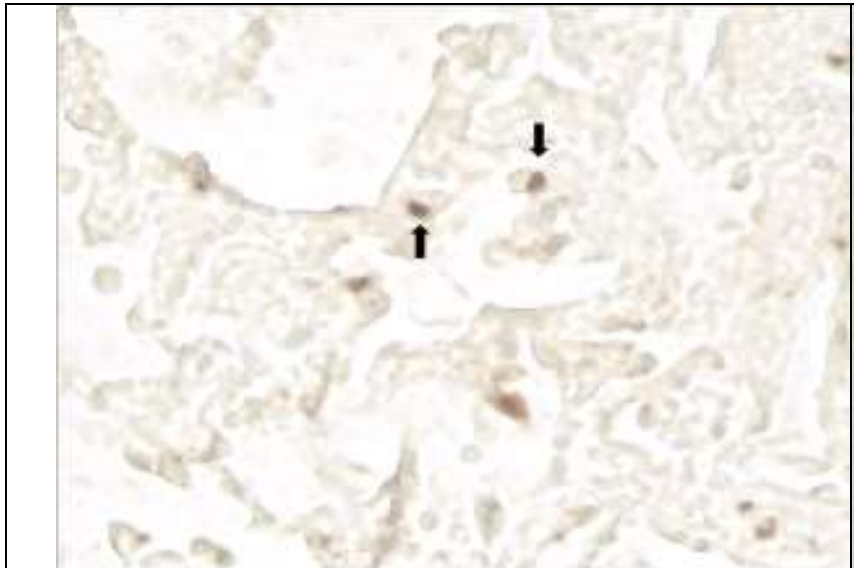

Figure 1.Section of lung showing pulmonary macrophages (arrows) in Bakerwali goat, 400X.

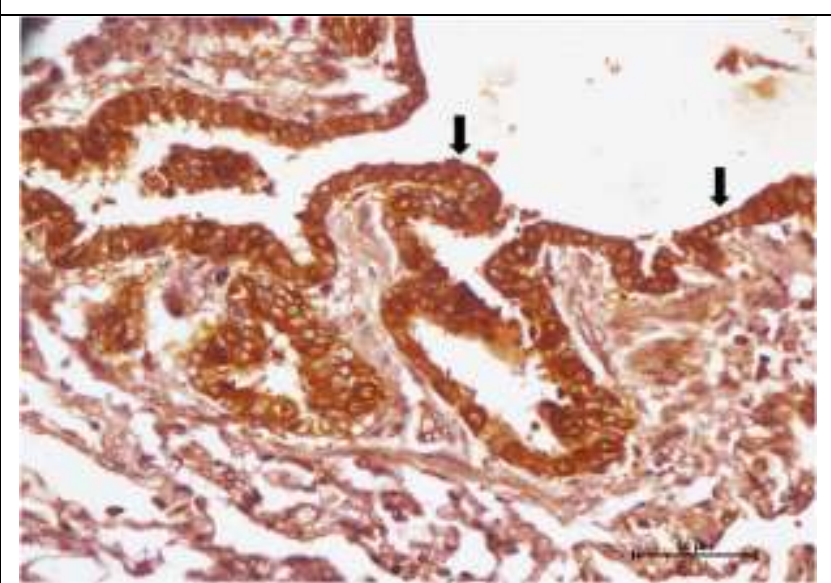

Figure 3.Immunostaining of goat lung showing strong to intense reaction of PCNA in the adult Pashmina goat. Polymer HRP method, 400X.

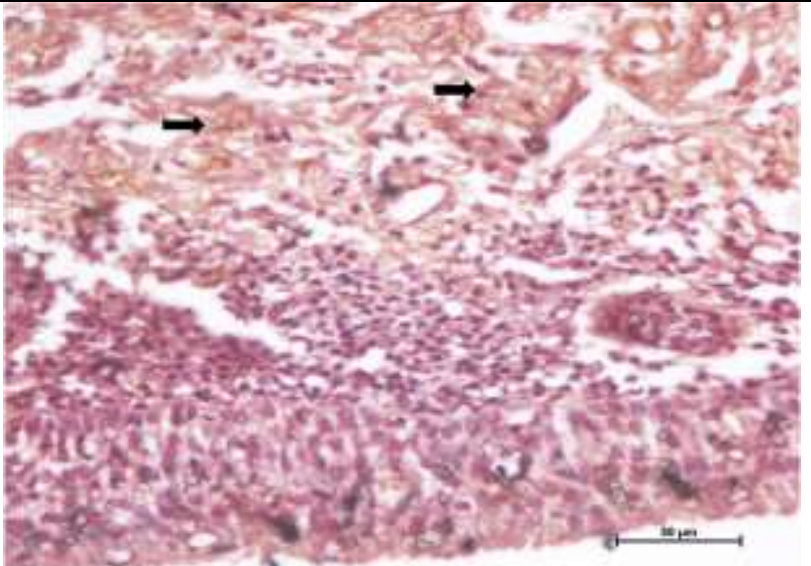

Figure 5.Immunostaining of trachea showing intense reaction of SMA in adult non-descript goat showing moderate reaction of SMA in sub mucosa. Polymer HRP method, 400X.

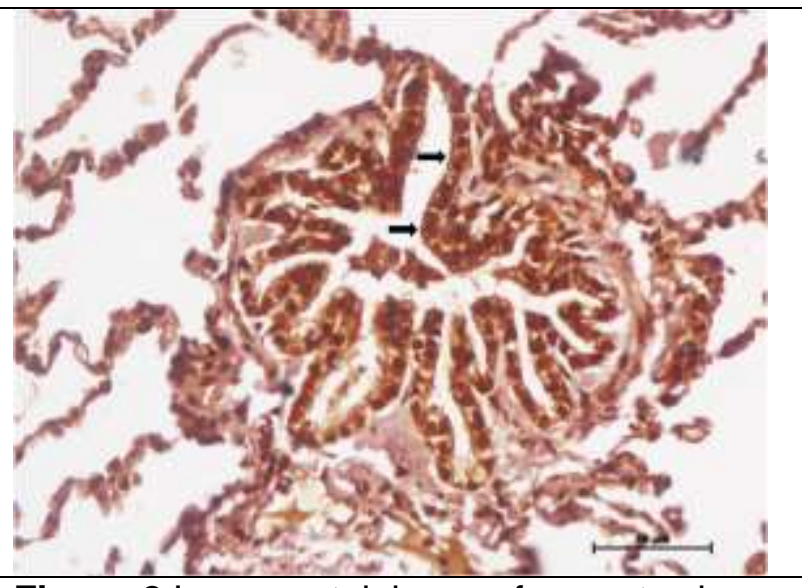

Figure 2.Immunostaining of goat lungs showing strong to intense reaction of PCNA in the adult Bakerwali goat. Polymer HRP method, 400X.

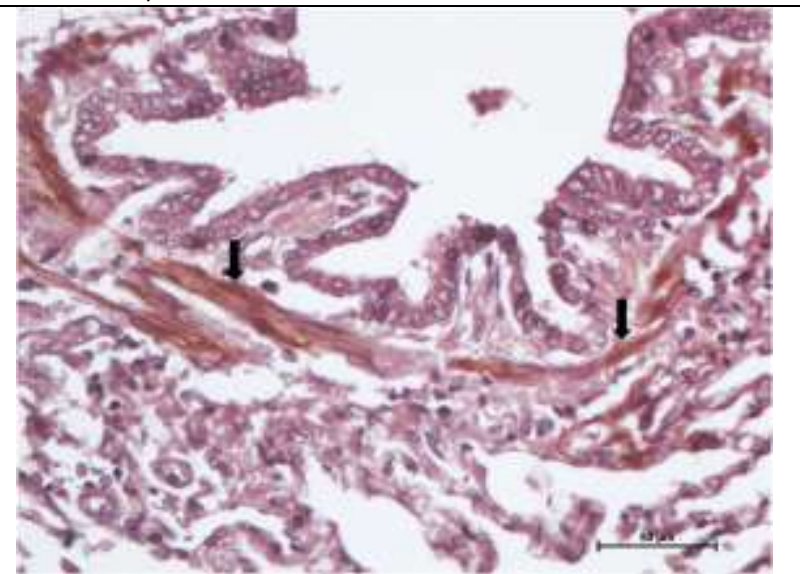

Figure 4. Immunostaining of goat lungs showing intense reaction of SMA in adult Pashmina goat. Polymer HRP method, 400X.

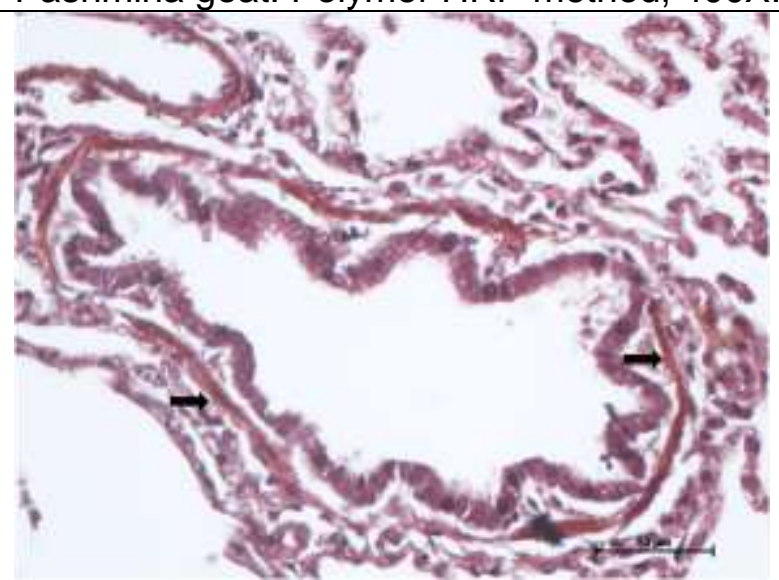

Figure 6.Immunostaining of lung showing strong reaction of SMA in bronchiole of adult non-descript goat. Polymer HRP method, $400 \mathrm{X}$. 


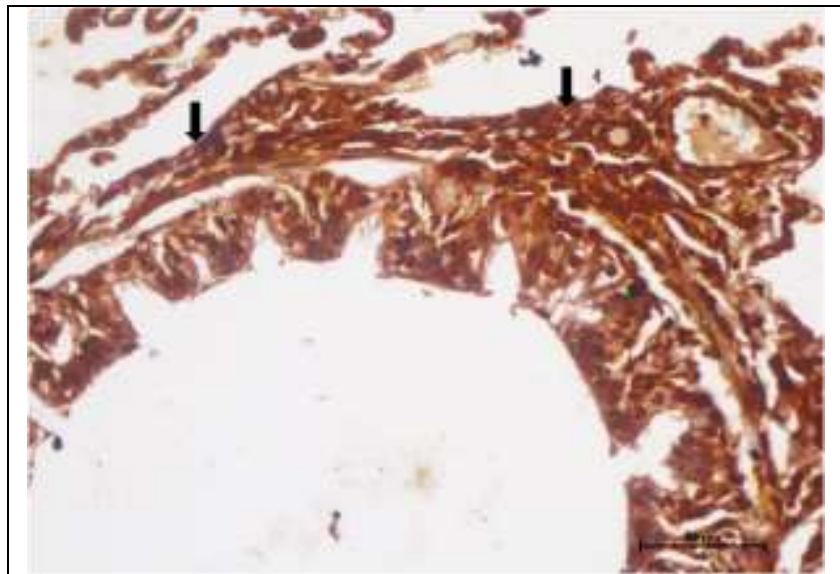

Figure 7.Immunostaining of lungs showing intense reaction of vimentin in adult Bakerwali goat. Polymer HRP method, 400X.

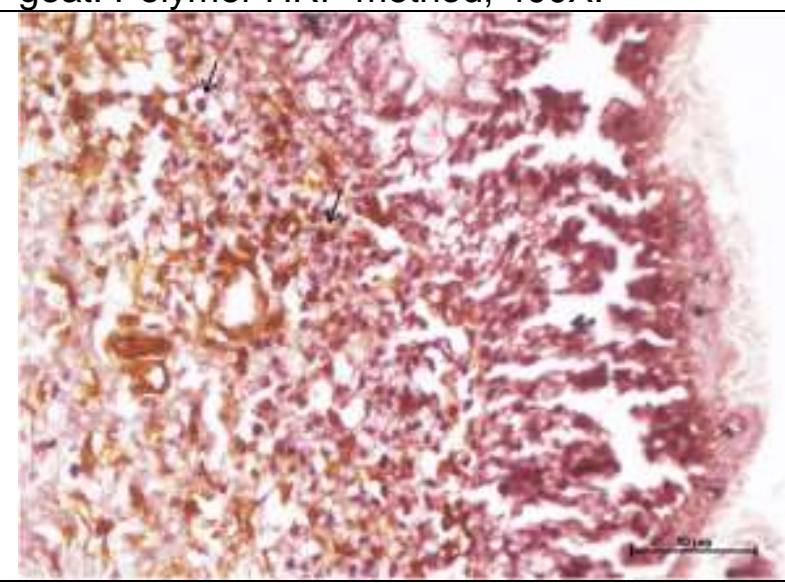

Figure 9.Immunostaining of trachea showing strong to intense reaction of vimentin positive cells (arrows) in adult Bakerwali goat. Polymer HRP method, 400X.

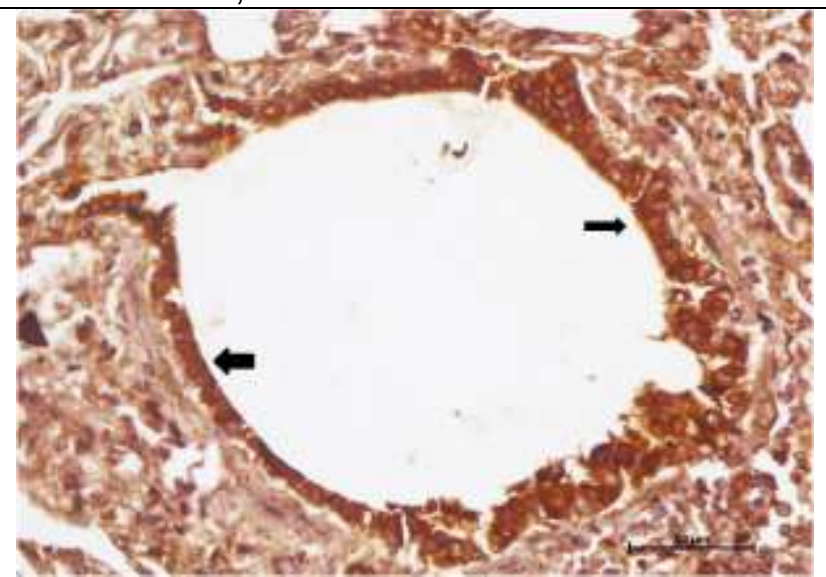

Figure 11. Immunostaining of lungs showing intense reaction of VEGF in bronchial epithelium (arrows) in adult Bakerwali goat. Polymer HRP method, 400X.

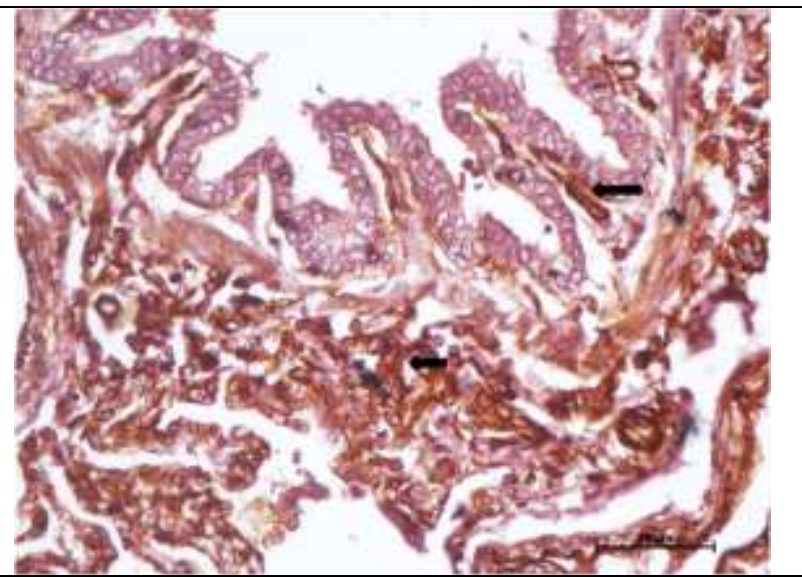

Figure 8.Immunostaining of lungs showing intense reaction of vimentin in adult nondescript goat. Polymer HRP method, 400X.

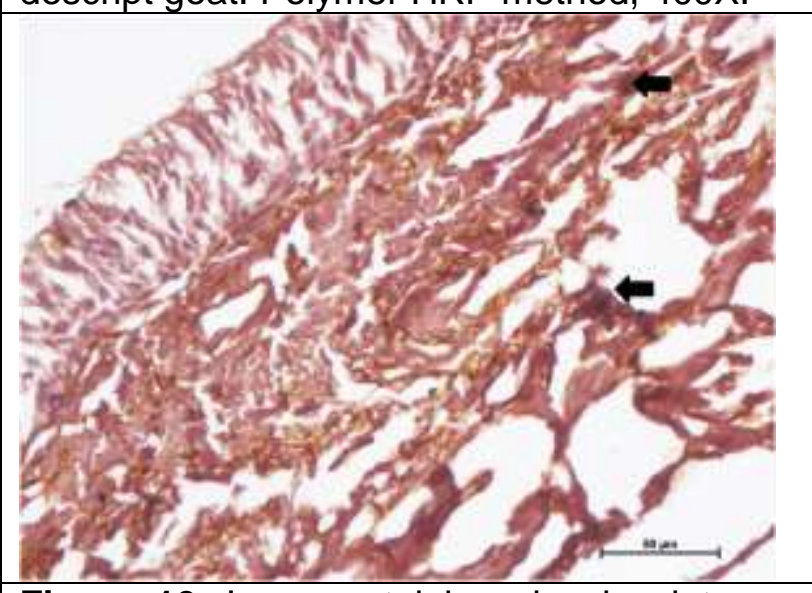

Figure 10. Immunostaining showing intense reaction of vimentin in tracheal submucosa (arrows) in adult non-descript goat. Polymer HRP method, 400X.

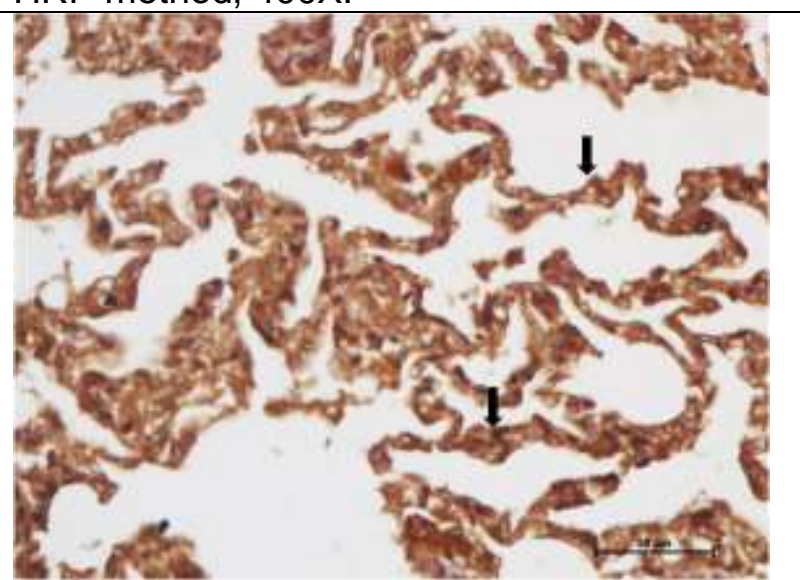

Figure 12. Immunostaining of lungs showing strong reaction of VEGF in the alveolar epithelium (arrows) in adult Pashmina goat. Polymer HRP method, 400X. 


\section{DISCUSSION}

\section{Lung macrophages}

In the present study, lung sections from goats showed normal alveolar septa, airways and large blood vessels. Large pulmonary macrophages were observed in the lung sections of all the three breeds of goat (Fig. 1). Macrophages were observed in the alveolar septa and airway epithelium. The mean macrophage count for Pashmina, Bakerwali and non-descript goat were recorded as $23.4 \pm 1.47,27.8 \pm 0.68$ and $21.4 \pm 0.70$, respectively.

Macrophages are phagocytic cells derived from blood monocytes that play an important role in innate immunity and steady-state homeostasis [9]. Macrophages within the lungs are highly heterogeneous based on their anatomical location, specialized function as well as their activation state [10,11]. Three types of macrophages have been identified in the lungs viz. alveolar macrophages (AMs), interstitial macrophages (IMs) and intravascular/marginated vascular macrophages that differ by location and function [12]. Alveolar macrophages mainly function in removing particles and microorganisms in the alveoli, whereas intravascular macrophages are believed to function in regulating tissue fibrosis, inflammation, and acting as antigen presenting cells [10]. Barletta and coauthors [12] reported that marginated vascular macrophages seem to function in the lung interstitium for recruiting neutrophils or myeloid cells. The existence of lung macrophage subsets with various functional properties needs additional analyses to better understand their contributions to lung disease pathogenesis [13]. The previous reports by Laskin and coauthors [11] reported that two types of macrophages were identified (AMS and IMs) in the lung tissue of humans and mice. Similarly, the reports of Warner and Brain [14] and Staub [15] showed that pulmonary macrophages were an important cell type in cattle, sheep, goats and pigs. The septal macrophages in the buffalo lungs had been demonstrated as in many other ruminants and horses [16, 17].

In the present study, lung sections from goats showed normal alveolar septa, airways and large blood vessels. Large pulmonary macrophages were present. Macrophages were observed in the alveolar septa and airway epithelium of the lungs. The mean macrophage count per field for Pashmina, Bakerwali and non-descript goat was $23.4 \pm 1.47,27.8 \pm 0.68$ and $21.4 \pm 0.70$, respectively. Our results were in corroboration with the findings of Sethi and coauthors [18] in Water buffalo, in which the macrophages were reported to have an intravascular location and the mean number of these cells per field was $12.16 \pm 0.25$. Higher number of pulmonary macrophages as recorded in our present study in goats might be species specific characteristics. The immunohistochemical data showed that the septal macrophages were located in septal capillaries and were in contact with the endothelium. The mean number of pulmonary macrophages as recorded in the present study was also comparable to the observations of Yanhui and coauthors [13] who reported that the alveolar and interstitial macrophages in lungs of rhesus macaques composed of $\sim 70 \%$ of immune responsive cells in the lungs. Alveolar macrophages represented a larger portion of macrophages, $\sim 75-80 \%$ and were the predominant immune cells in the lungs.

\section{Proliferating cell nuclear antigen (PCNA)}

The PCNA activity was intense in the alveolar epithelial cells of lungs in Pashmina and Bakerwali goats. Also, the activity was very high in the lung tissue of non-descript goat. The PCNA activity was intense in the bronchial epithelial cells of lungs in Bakerwali goat (Figures. 2, 3).

Proliferating cell nuclear antigen, a highly conserved auxiliary protein for the DNA polymerase $\delta$, is greatly increased in proliferating cells as compared with mitotically quiescent cells [19, 20]. Cycling (PCNA) is absent or present in very low amounts in normal non-dividing cells and tissues, but it is synthesized in variable amounts by proliferating cells of both normal and transformed origin [21].

In the present study, the PCNA activity was found intense in the alveolar epithelial cells of lungs in Pashmina and Bakerwali goats. Also, the activity was very high in the lung tissue of non-descript goat. Such dominating presence of PCNA in the alveolar lining cells indicated that these cells of all the goat breeds under study were physiologically highly active. The PCNA activity was also intense in the bronchial epithelial cells of lungs in Bakerwali goat. According to previous studies, PCNA has so far been detected in proliferating cultured cells (S-phase cells) from the various vertebrate species viz.aves, bat, bovine, dog, dolphin, goat, hamster, human, mink, monkey, mouse, Pisces, rabbit and rat [19, 22]. Most normal human tissues including aorta, bladder, cerebellar cortex, cerebral cortex, cornea, heart muscle, larynx, lung, pharynx, thyroid gland, trachea have been analyzed for PCNA. Also, many newborn mouse tissues (gut, spleen, kidney, liver, lungs) exhibit high levels of PCNA [23, 24]. 


\section{Smooth muscle actin (SMA)}

Strong reaction of SMA was observed in the submucosa of bronchioles of Pashmina and Bakerwali goats. The submucosa of the tracheal tissue showed a strong reaction of SMA in the non-descript goat. There was a moderate reaction of SMA in the submucosa of trachea in this Bakerwali goat(Figures. 4, 5, $6)$.

Alpha-smooth muscle actin (alpha-SMA) is the actin isoform. It predominates within vascular smoothmuscle cells and also plays an important role in fibrogenesis [25]. Myofibroblast cells are morphologically and metabolically distinctive fibroblasts that express alpha-SMA, and their activation plays a major role in development of the fibrotic response [26]. These myofibroblasts express $\alpha$-smooth muscle actin ( $\alpha$-SMA) and possess contractile and secretory properties that are important in controlling tissue architecture. The myofibroblasts found in the peripheral and sub pleural regions of fibrosis express a-SMA, vimentin, and

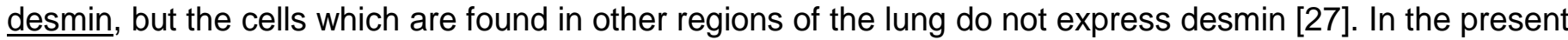
study, the submucosa of the tracheal tissue showed a strong reaction of SMA in non-descript goat, while a moderate reaction of SMA was observed in the submucosa of trachea in Bakerwali goat. Strong reaction of SMA was observed in the submucosa of bronchioles of Pashmina and Bakerwali goats. This indicated that the myofibroblasts around the pulmonary bronchioles were very active in these two goat types as compared to non-descript goats. In case Pashmina goat, it might be co related with its adaptation to the high altitude hypoxic cold conditions of its habitats. Similarly this might have a link with the exposure of Bakerwali goats to varied environmental conditions with different altitudes as these goats have typical migratory behavior. Takashi and coauthors [28] also reported that immunohistochemical staining of rat lungs showed $\alpha$-smooth muscle actin mostly in the vessel wall. However, paucity of available literature restricted us to compare with the present study.

\section{Vimentin}

A number of vimentin-positive cells were found in the lung parenchyma in Pashmina and Bakerwali goats. Also, there was a strong reaction of vimentin mainly in submucosal area in the non-descript goat. The tracheal submucosa showed an intense reaction of vimentin in the submucosa in all the goats (Figures. 7, 8, 9, 10).

Vimentin, also known as fibroblast intermediate filament, is the major intermediate filament found in non-muscle cells [29]. These cell types include fibroblasts, endothelial cells, macrophages, melanocytes, Schwann cells, and lymphocytes. In our study, a number of vimentin-positive cells were found in the lung parenchyma in Pashmina, Bakerwali and non-descript goats. The tracheal submucosa showed an intense reaction of vimentin in all the goats. However, weak reaction to vimentin was observed in the lung tissue of the goats. Takashi and coauthors [28] also reported that the immunohistochemistry for vimentin showed weak immunostaining in the normal rat lung tissues.

\section{Vasculo-endothelial growth factor (VEGF)}

The VEGF activity was found to be intense in the lungs of Bakerwali goat. Also, the reaction was strong in alveoli in Pashmina and non-descript goats (Figures. 11, 12).

Vascular endothelial growth factor (VEGF) is a pluripotent growth and permeability factor. It has a broad impact on endothelial cell function. The lung tissue is very rich in this protein and many different lung cells produce VEGF and also respond to VEGF. VEGF is critical for the development of the lung and serves as a maintenance factor during adult life [30]. The lung contains the highest level of transcripts amongst a wide range of organs that express VEGF [31]. VEGF is also necessary for the formation of vascular beds of several organs during embryonic development. In the present study, the VEGF activity was found to be weak in the tracheal tissue in all the goats. However, the activity of VEGF was found to be intense in the lungs of Bakerwali goat and the reaction was strong in alveoli in Pashmina and non-descript goats. Such strong activity of VEGF found in the lung tissue of all the goats might serve as a good maintenance factor for the wear and tear of the same. Our findings were also corroborated with the findings of Monacci and coauthors [31] who stated that the lung contains the highest level of transcripts amongst a wide range of organs that express VEGF [31]. 


\section{CONCLUSION}

The expression of various proteins such as Vimentin, SMA, PCNA and VEGE did not show a definitive trend among the goat breeds and hence they may not be so useful as markers while studying effect of altitudes on the respiratory tissue in animal models.

\section{REFERENCES}

1. Jay FS. Hemoglobin function and physiological adaptation to hypoxia in high-altitude mammals. J Mammal.2007 Jan; 88 (1): 24-31.

2. Hare WCD. Respiratory System In: The Anatomy of the Domestic Animals. $5^{\text {th }}$ edn. Vol. 1.by R. Getty, W.B .Saunders Company; 1975. p. 511-514, 518-523, 926-933, 1290-1294, 1567- 1572.

3. Suman AN, Gupta AK, Jain RK. Histomorphology and histochemistry of respiratory bronchiole during postnatal development in goat. HaryVet. 2005; 44: 55-59.

4. Danacu V, Raita S, lonita C, Seicaru A. Research microscopic morphology of lung in small ruminants. Lucrăriștiințifice - MedicinăVeterinară, Universitatea de ȘtiințeAgricoleșiMedicinăVeterinară "Ion Ionescu de la Brad" lași. 2015 Jan; 58(1): 11-16.

5. Baba MA, Choudhary AR. Histomorphology of the Pulmonary Alveoli of goat (Capra hircus).Vet World. 2008 Oct; 1(10): 312-313.

6. Kumar SR, Nagamalleswari Y, Kumar DP. Ultrastructural study of lung in adult non-descript Indian goat (Capra hircus). Ind J Vet Anat. 2013 Jan; 25(1): 33-35.

7. Kalita A. Histomorphological Study of the Respiratory System of Mizo Local Pig. Asian J Biomed Pharma. Sci. 2014 Sep; 4(9): 50-54.

8. Luna LG. Manual of histologic staining methods of Armed Forces Institute of Pathology, $3^{\text {rd }}$ edn. McGraw Hill Book Co., New York. 1968.

9. Silverstein AM. Ilya Metchnikoff, the phagocytic theory, and how things often work in science. J Leuko Biol. 2011; 90: 409-410.

10. Schneberger D, Aharonson K, Singh B. Monocyte and macrophage heterogeneity and Toll-like receptors in the lung. Cell Tissue Res. 2011; 343: 97-106.

11. Laskin DL, Weinberger B, Laskin JD. Functional heterogeneity in liver and lung macrophages. J Leuko Biol. 2001; 70: 163-170.

12. Barletta KE, Cagnina RE, Wallace KL, Ramos SI, Mehrad B, Linden J. Leukocyte compartments in the mouse lung: distinguishing between marginated, interstitial and alveolar cells in response to injury. $\mathrm{J}$ Immunol Meth. 2012; 375: 100-110.

13. Yanhui C, Chie S, Mariluz A, Xavier A, Elizabeth SD, Marcelo JK. In Vivo Characterization of Alveolar and Interstitial Lung Macrophages in Rhesus Macaques: Implications for Understanding Lung Disease in Humans. J Immunol.,doi:10.4049/jimmunol.1302269. 2017.

14. Warner AE, Brain JD. The cell biology and pathogenic role of pulmonary intravascular macrophages. Am J Physiol. 1990; 258: L1-L12.

15. Staub NC. Pulmonary intravascular macrophages. Ann Rev Physiology. 1994; 56:47-67.

16. Atwal OS, Saldanha KA. Erythrophagocytosis in alveolar capillaries of goat lung: ultrastructural properties of blood monocytes. Acta Anat. 1985; 124:245-254.

17. Atwal OS, Singh B, Staempfli H, Minhas K. Presence of pulmonary intravascular macrophages in the equine lung: some structure- functional properties. Anat Rec. 1992 Apr; 234(4): 530- 540.

18. Sethi RS, Brar RS, Singh O, Singh B. Immunolocalization of Pulmonary Intravascular Macrophages, TLR4, TLR9 and IL-8 in Normal and Pasteurellamultocida-infected Lungs of Water Buffalo (Bubalusbubalis). J Comp Path. 2010 Feb; 144 (2-3): 135-144.

19. Celis JE, Bravo R, Larsen PM, Fey SJ. Cyclin: a nuclear protein whose level correlates directly with the proliferative state of normal as well as transformed cells. Leuko Res. 1984; 8:143.

20. Fairman MP. DNA polymerase ס/PCNA: actions and interactions. J Cell Sci. 1990; 95:1.

21. Bravo R, Celis JE. A search for differential polypeptide synthesis throughout the cell cycle of HeLa cells $\mathrm{J}$ BioChem. 1980; 48:795-802.

22. Franza BR, Garrels JI. Transformation sensitive proteins of REF 52 cells detected by computer-analyzed two dimensional gel electrophoresis.Cancer Cells. 1984; 1:137-146.

23. Bravo R, Fey SJ, Bellatin J, Mose LP, Arevalo J, Celis JE. Exp Cell Res. 1981; 136:319-337.

24. Mose L P. An assessment of the Potential Offered by Two Dimentional gel electrophoresis and silver staining in developmental Biology. Cand. Sci. dissertation, Aarhus University, Aarhus, Denmark. 1981. 
25. Kawasaki Y, Imaizumi T, Matsuura H, Ohara S, Takano K, Suyama K, et al. Renal expression of alpha-smooth muscle actin and c-Met in children with Henoch-Schonlein purpura nephritis. Pediatr Nephrol. 2008; 23:913-919.

26. Shen C, Jenny Y, Hongbao M. Alpha-Smooth Muscle Actin ( $\alpha$-SMA). The J Am Sci. 2008 Apr; 4(4):7-9.

27. Lynne AM, Darryl AK, Geoffrey JL. Asthma and COPD, $2^{\text {nd }}$ edn. Basic management and clinical management, 2009: 193-200.

28. Takashi T, Arifa N, Abdulmonem A, Khadijah AT, Mohammed SR. Heat Shock Protein 47: A Novel Biomarker of Phenotypically Altered Collagen-Producing Cells. Acta Histocheia et Cytochemia. 2011 Feb; 44 (2): 35-41.

29. Colvin RB, Bhan AK, McCluskey RT. Diagnostic Immunopathology. New York: Raven Press. 1995.

30. Voelkel NF, Vandivier RW, Tuder RM. Vascular endothelial growth factor in the lung. Am J Phy-Lung Cellular MolPhy. 2006 Feb; 290(2):209-21.

31. Monacci WT, Merrill MJ, Oldfield EH. Expression of vascular permeability factor/vascular endothelial growth factor in normal rat tissue. Am J Phy. 1993; 364:995-1002.

(C) 2021 by the authors. Submitted for possible open access publication under the terms and conditions of the Creative Commons Attribution (CC BY NC) license (https://creativecommons.org/licenses/by-nc/4.0/). 